2-17-2014

\title{
The Appropriateness of Different Modes of Strategy from a Product-Market Perspective
}

Tilottama G. Chowdhury

Quinnipiac University

Sreedhar Madhavaram

Cleveland State University, s.madhavaram@csuohio.edu

S. Ratneshwar

University of Missouri

Rhetta Standifer

University of Wisconsin - Eau Claire

Follow this and additional works at: https://engagedscholarship.csuohio.edu/bus_facpub

Part of the Strategic Management Policy Commons

How does access to this work benefit you? Let us know!

\section{Publisher's Statement}

This is an Author's Accepted Manuscript of an article published in Journal of Strategic Marketing 02-17-2014, available online: 10.1080/0965254X.2014.885988

\section{Original Published Citation}

Chowdhury, T. G., Madhavaram, S., Ratneshwar, S., Standifer, R. (2014). The Appropriateness of Different Modes of Strategy from a Product-Market Perspective. Journal of Strategic Marketing.

This Article is brought to you for free and open access by the Monte Ahuja College of Business at EngagedScholarship@CSU. It has been accepted for inclusion in Business Faculty Publications by an authorized administrator of EngagedScholarship@CSU. For more information, please contact library.es@csuohio.edu. 


\title{
The appropriateness of different modes of strategy from a product-market perspective
}

\author{
Tilottama G. Chowdhury", Sreedhar Madhavaram ${ }^{\mathrm{b} *}$, S. Ratneshwar" and \\ Rhetta Standifer ${ }^{\mathrm{d}}$ \\ ${ }^{a}$ Department of Marketing and Advertising, Quinnipiac University, Hamden, CT, USA; ${ }^{b}$ Department \\ of Marketing, Cleveland State University, 1860 E. 18th Street, Euclid Avenue, Cleveland, OH 44115 , \\ USA; ${ }^{c}$ Marketing, University of Missouri, Columbia, MO, USA; ${ }^{\circ}$ Department of Management and \\ Marketing, University of Wisconsin-Eau Claire, Eau Claire,
}

WI, USA

\begin{abstract}
Strategy-making is an important yet complex task. The present research examines the issue of strategy mode, that is, the manner or style in which strategy is determined in an organization. Prior researchers have proposed various typologies for strategy modes. However, research into which strategy modes are appropriate to what kinds of firm situations and contexts has been limited. Specifically, there has been no research that explores strategy modes from a marketing environment perspective. Given that research at the intersection of marketing and management disciplines has often produced mutually beneficial, rich insights, we approach strategy modes from a product-market perspective and examine the normative appropriateness of different strategy modes with reference to firms' external and internal environments. The research also explores the relevance and value of combining various strategy modes in regard to different stages of the product-market life cycle. In exploring strategy modes and their combinatory influences from a product-market perspective, we develop specific propositions. The paper concludes with a discussion of implications for academics and practitioners.
\end{abstract}

Keywords: organizational strategy; strategy modes; product-markets; product-market lifecycle

\section{Introduction}

Strategy-making is important yet complex. Consequently, over the years, strategy theorists have often sought to describe and evaluate different strategy-making processes, i.e., strategy modes (e.g., Allison, 1971; Mintzberg, 1973; Nonaka, 1988; Nutt, 1981). Scholars have also suggested links between different strategic modes and organizational structures and characteristics (e.g., Chaffee, 1985; Hart, 1992; Makadok \& Barney, 2001; Miles \& Snow, 1978; Parnell \& Lester, 2003; Slater \& Olson, 2001). In addition, some research exists on the relationships between strategy-making and firm performance (e.g., Hart \& Banbury, 1994; Tegarden, Sarason, \& Banbury, 2003). Nonetheless, despite the criticality of external environment and firm situations and contexts for business and marketing strategy (Dugal \& Roy, 1996; Varadarajan, 2011), rarely have researchers inquired into which strategy modes are appropriate to what kinds of firm situations and contexts. Specifically, there is no research that explores the issue of strategy mode (i.e., manner or style in which strategy is determined in an organization) from a marketing environment

*Corresponding author. Email: s.madhavaram@csiohio.edu 
perspective. Furthermore, because research at the intersection of marketing and management disciplines has often produced mutually beneficial, rich insights, it is worth exploiting the synergies between marketing and management theories (Ketchen \& Hult, 2011).

Therefore, the present research addresses this gap in the literature by examining strategy modes from a product-market perspective. In terms of this perspective, firms are conceptualized as bundles of different product/service offerings, and competition with other firms is at the level of customer needs and solutions that define product-markets (e.g., Day, Shocker, \& Srivastava, 1979; Ratneshwar, Shocker, Cotte, \& Srivastava, 1999). Our inquiry uses Hart's (1992) framework of strategic modes as a foundation. We use Hart's (1992) typology for two important reasons. First, unlike prior research on strategy-making that focuses on a limited set of actors (e.g., top managers) with regards to strategy-making, Hart (1992) views strategy-making as an organization-wide phenomenon. Second, Hart's (1992) framework for strategy-making processes (i.e., strategy modes) is comprehensive as well as integrative in that it (1) takes into account 11 previous typologies from the strategy-making literature; (2) efficiently categorizes them into three broad themes, rationality, vision, and involvement; and (3) delineates a typology with five key strategy modes, namely, the command, symbolic, rational, transitive, and generative modes.

From a product-market perspective, the specific situations and contexts that firms find themselves in are framed by external and internal environments. In fact, it is well established that firm performance requires appropriate match of strategy to internal (Calantone, di Benedetto, \& Bhoovaraghavan, 1994) as well as external (Calantone et al., 1994; Karakaya \& Kerin, 2007; Pelham, 1999) environments. Indeed, some past research has looked into the role of the external environment in the context of strategyperformance relationships and strategy modes. For example, while McArthur and Nystrom (1991) examine different environmental dimensions (dynamism, complexity, and munificence) as moderators for strategy-performance relationships, Tegarden et al. (2003) suggest that the relationship between strategy-making processes and firm performance is moderated by environmental dynamism. However, in Tegarden et al.'s (2003) work, environmental dynamism mainly captures changes in technology and demand; other important factors such as changes in competition are not considered. Therefore, a more comprehensive exploration into the relationship between strategy modes and external environmental characteristics is required. Moreover, past research has not looked into relationships between different strategy modes and particular management activities (e.g., market research, customer profitability analysis, new product launch, etc.). In terms of a product-market perspective, there have been calls to investigate life-cycle stage as a dependent as well as an independent variable with regards to strategy formation (Hooley, 1995). In fact, for Nadeau and Casselman (2008), the product-market perspective is highly relevant for strategy formulation and development. Therefore, we address this gap by including in our examination the key activities that management has to perform from a product-market perspective (Ratneshwar et al., 1999).

Another major objective of our research is to explore the appropriateness of strategy modes for different product-market lifecycle (PLC) stages (for a review of PLC research, see Rink \& Swan, 1979). The complexity of the marketing environment varies for products in different product-market life cycle stages (Day, 1981). For instance, the strategic issues for a firm producing bio-engineering products that are currently in the introduction stage are likely to differ substantially from those of a financial services firm whose retirement products are in the maturity stage. Our linking strategic modes to product-market factors and product-market life cycle stages is also motivated by prior 
literature which documents product development as a major source of competitive advantage (Brown \& Eisenhardt, 1995; Gatignon \& Xuereb, 1997). It is through effective innovation and product management that organizations diversify, adapt, and re-invent their firms (Schoonhoven, Eisenhardt, \& Lyman, 1990). Therefore, as external environments for product management change over time and as product-markets pass through different life cycle stages, strategy and structure need to evolve appropriately. Correspondingly, we argue that strategy-making processes also need to adapt dynamically. More specifically, building on the ideas of Hart (1992) and Hart and Banbury (1994), we propose that rather than employing a single strategy mode, combining specific, complementary strategy modes for different stages of the product-market life cycle may be optimal.

The remainder of this paper is organized as follows. First, we provide an overview of Hart's (1992) strategy modes framework. Second, we explore the fit between the different strategy modes and firm's internal and external environments from a product-market perspective and develop corresponding propositions. Third, we examine the appropriateness of various strategy modes for different stages of the product-market life cycle. In doing so, we also explore the concept of combinatory strategy modes for different stages of product-market life cycle and develop relevant propositions. We then conclude with a discussion of our paper's contributions, limitations, and implications for academics and practitioners.

\section{Five different strategy modes}

Hart's (1992) discussion of strategy modes acknowledges the existence of various different strategy typologies and provides a comprehensive, integrative framework for the strategy-making process. Hart's (1992) framework consists of a typology of five different strategy modes, namely, the command, symbolic, rational, transactive, and generative modes. This classification system is based on the role played by top management and other organizational members in the strategy development process in regard to the dimensions of rationality, vision, and involvement. We discuss below the characteristics of each of the five strategy modes (see also Table 1).

In the command mode, power is centralized around top management (Mintzberg, 1973), usually involving a single individual or a small group of top managers who control the strategic planning process, typically utilizing deliberate analyses of alternative courses of actions. Thus, top management commands, and other organizational employees execute the plan of action (Hart, 1992). Therefore, such a mode is appropriate for small organizations with a hierarchical structure, well-defined tasks (Løwendahl \& Revang, 1998), and a top-down decision-making style.

The symbolic mode emphasizes a clear, compelling corporate mission and affirmation of a strong sense of identity to the employees (Hart, 1992). The organizational environment is based on shared values (Pascale, 1985; Weick, 1987), encouraging creative actions, a strong sense of commitment, and high levels of employee achievement. Furthermore, while emphasizing organizational mission and change, firms often use shortterm goals to promote a strong sense of commitment to the corporate mission amongst the employees. This results in increased employee bargaining power, team-based processes, a proactive environment, and typically an implicit rather than explicit control system.

The rational mode entails comprehensive planning and analysis (cf. competitive analysis; Porter, 1980), typically done in a sequential, step-by-step manner (Hart, 1992). Such planning includes determination of an organization's long-term goals and subsequently determination of necessary actions and resource allocations (Chandler, 
Table 1. Hart's (1992) alternative strategy modes.

\begin{tabular}{|c|c|c|c|c|c|}
\hline & Command & Symbolic & Rational & Transactive & Generative \\
\hline $\begin{array}{l}\text { Summary } \\
\text { description" }\end{array}$ & $\begin{array}{l}\text { Small top management } \\
\text { with a comprehensive } \\
\text { business plan controlling } \\
\text { the strategy processes. } \\
\text { - Efficient implementation } \\
\text { of a well articulated } \\
\text { strategy }\end{array}$ & $\begin{array}{l}\text { A clear corporate } \\
\text { mission \& vision } \\
\text { provides a sense of } \\
\text { identity to the employees } \\
\text { and inspire creative } \\
\text { actions from them } \\
\text { - Weaving short term } \\
\text { goals into a company } \\
\text { dream in a proactive } \\
\text { environment }\end{array}$ & $\begin{array}{l}\text { Formal plan, } \\
\text { implement actions, } \\
\text { and resource allocations } \\
\text { through step-by-step } \\
\text { processes for achieving } \\
\text { predetermined objectives }\end{array}$ & $\begin{array}{l}\text { - Emphasis on } \\
\text { interaction and } \\
\text { learning along with } \\
\text { ongoing dialogue } \\
\text { with stakeholders }\end{array}$ & $\begin{array}{l}\text { - Autonomous behavior } \\
\text { of organizational } \\
\text { members; top managers } \\
\text { screen potential } \\
\text { proposals emerging } \\
\text { from below }\end{array}$ \\
\hline $\begin{array}{l}\text { Organization } \\
\text { characteristics and } \\
\text { decision-making } \\
\text { style for strategy } \\
\text { effectiveness }\end{array}$ & $\begin{array}{l}\text { - Hierarchical organization } \\
\text { structure (especially when } \\
\text { the organization is small) } \\
\text { - Centralized at the top } \\
\text { - Top-down decision } \\
\text { making }\end{array}$ & $\begin{array}{l}\text { - High employee } \\
\text { bargaining power } \\
\text { - Empowered employees } \\
\text { - Team-based processes } \\
\text { - Proactive strategy-making } \\
\text { - Implicit control system }\end{array}$ & $\begin{array}{l}\text { - Hierarchical } \\
\text { organization structure } \\
\text { (especially when the } \\
\text { organization is large) } \\
\text { - Top-down decision } \\
\text { making }\end{array}$ & $\begin{array}{l}\text { - Decentralized } \\
\text { organization } \\
\text { structure } \\
\text { - Participative } \\
\text { environment } \\
\text { - Technology } \\
\text { inter-dependencies } \\
\text { - Propensity to } \\
\text { experiment } \\
\text { - Learning mindset } \\
\text { - Horizontal } \\
\text { organization } \\
\text { structure } \\
\text { - Customer-oriented } \\
\text { organization } \\
\text { - Cross-functional } \\
\text { communication } \\
\text { - Analyzer } \\
\text { strategy- making } \\
\text { - Lateral decision } \\
\text { making }\end{array}$ & $\begin{array}{l}\text { Prospector } \\
\text { strategy-making } \\
\text { Bottom-up decision } \\
\text { making }\end{array}$ \\
\hline
\end{tabular}

${ }^{3}$ The table provides a brief overview of the five strategy modes based on Hart (1992)'s definitions. 
1962). Formalized strategic planning may include elements such as portfolio analysis and competitive analysis (Porter, 1980), involving considerable information processing and exchanges between the external and the internal environments of the organization. The fact that there may be several possible ways of attaining a chosen long-term goal requires the evaluation of various alternative courses of action which, in turn, implies a highly structured decision-making process. Such a process is characterized by systematic steps wherein the organization identifies desirable future outcomes and then determines the causal chain of activities that is most likely to produce those particular outcomes. Hence, the rational mode implies a highly structured decision-making process, typically one that is appropriate for a large, tightly-coupled, hierarchical organization structure (Chaffee, 1985; Hart, 1992; Løwendahl \& Revang, 1998).

The main objective of the transactive mode is to make strategic decisions based on communication or transaction exchanges with important stakeholders in order to adapt with the environment emphasizing interaction and learning via ongoing dialogue with suppliers, employees, governments, and customers (Hart, 1992). Given this mode's focus on learning and feedback, it is most appropriate for organizations with a participative environment and a decentralized, loosely integrated, horizontal structure. Accordingly, the transactive mode assumes a highly permeable boundary between the organization and the market environment. The strength of this mode lies in its power to attract and retain enough customers as well as employees - whose cooperation enables proper functioning of the organization (Løwendahl \& Revang, 1998).

Finally, the generative mode involves autonomous behavior of organizational members (Hart, 1992). Top managers screen potential proposals emerging from lower organizational levels (Mintzberg \& McHugh, 1985) and focus on ongoing adjustments and product championships. Thus, this type of intrapreneurship-based strategic development should be most appropriate for organizations which engage in bottom-up decisions and encourage experimentation and risk-taking. This completes our overview of the five strategy modes, specifically, how each is defined in terms of Hart's (1992) framework and the organizational characteristics and decision-making styles that can make a particular strategy mode effective. We now examine the fit between the various strategy modes and product-market characteristics.

\section{Strategy modes and product-market characteristics}

In this section, we first identify key environmental characteristics and management activities relevant to product-market performance. Then, we explore the ideal market and organizational characteristics for each mode of strategy. We also probe the appropriateness of each strategy mode for effectively carrying out specific productmarket activities. Later, we use these linkages to tie the various strategy modes to different stages of the product-market life cycle. The unit of analysis here is a management team that is primarily concerned with a single product line or strategic business unit (SBU) that competes in a specific product-market.

\section{Environmental characteristics and management activities}

We introduce here environmental characteristics and management activity concepts, focusing on those that are crucial to strategy-making based on existing literature and would help us identify key differences between Hart's strategy modes. The main points of our analysis are summarized in Tables 2 and 3 , where we specifically indicate the degree 
Table 2. How different strategy modes fit with environmental characteristics.

\begin{tabular}{lccccc}
\hline Specific environmental characteristics & Command & Symbolic & Rational & Transactive & Generative \\
\hline Growing markets & $\mathrm{L}$ & $\mathrm{H}$ & $\mathrm{L}$ & $\mathrm{L}$ & $\mathrm{M}$ \\
Unstable markets & $\mathrm{L}$ & $\mathrm{H}$ & $\mathrm{L}$ & $\mathrm{L}$ & $\mathrm{H}$ \\
Mature markets & $\mathrm{M}$ & $\mathrm{L}$ & $\mathrm{M}$ & $\mathrm{H}$ & $\mathrm{M}$ \\
Predictable market environment & $\mathrm{H}$ & $\mathrm{L}$ & $\mathrm{H}$ & $\mathrm{M}$ & $\mathrm{L}$ \\
More complex environment & $\mathrm{L}$ & $\mathrm{M}$ & $\mathrm{L}$ & $\mathrm{H}$ & $\mathrm{H}$ \\
Fragmented, changing environment & $\mathrm{L}$ & $\mathrm{M}$ & $\mathrm{L}$ & $\mathrm{M}$ & $\mathrm{H}$ \\
Stable competition & $\mathrm{H}$ & $\mathrm{L}$ & $\mathrm{H}$ & $\mathrm{M}$ & $\mathrm{L}$ \\
Environmental turbulence & $\mathrm{L}$ & $\mathrm{H}$ & $\mathrm{L}$ & $\mathrm{L}$ & $\mathrm{H}$ \\
Increasing number of competitors & $\mathrm{L}$ & $\mathrm{H}$ & $\mathrm{L}$ & $\mathrm{L}$ & $\mathrm{M}$ \\
Moderate entry barriers & $\mathrm{M}$ & $\mathrm{H}$ & $\mathrm{L}$ & $\mathrm{M}$ & $\mathrm{M}$ \\
High entry barriers & $\mathrm{H}$ & $\mathrm{L}$ & $\mathrm{H}$ & $\mathrm{L}$ & $\mathrm{L}$ \\
Capital-intensive businesses & $\mathrm{M}$ & $\mathrm{L}$ & $\mathrm{H}$ & $\mathrm{L}$ & $\mathrm{L}$ \\
Licensing and/or regulatory protection & $\mathrm{M}$ & $\mathrm{L}$ & $\mathrm{H}$ & $\mathrm{L}$ & $\mathrm{L}$ \\
High customer bargaining power & $\mathrm{L}$ & $\mathrm{L}$ & $\mathrm{L}$ & $\mathrm{H}$ & $\mathrm{M}$ \\
\hline
\end{tabular}

Note: ' $H$ ', high degree of match; ' $M$ ', moderate degree of match; ' $L$ ', low degree of match.

of match or fit (i.e., whether high, moderate, or low) between each of the listed environmental characteristics and management activities and the five strategy modes. First, as shown in Table 2, we focus on the product-market maturity (D'Souza \& Rao, 1995) and the stability and predictability of the market environment. We also examine the extent of environmental turbulence, existing competition and entry barriers (Han, Kim, \& Kim, 2001), licensing (Kotabe, Sahay, \& Aulakh, 1996), and regulatory protection in the market environment. Second, as shown in Table 3, we look into a wide array of management activities that impact organizational performance, focusing on five broad areas of management activities, namely, (i) customer-related activities, (ii) employee-related activities, (iii) environmental-oriented activities, (iv) process activities, and (v) launch activities.

\section{Customer-related activities}

Today's marketing world realizes the need for customer centricity, which quite often is reflected in the use of customer data in market responsive decisions (Kohli \& Jaworski, 1990), often customized to a specific customer segment. We focus on the following customer-related activities: (i) understand customer profitability, (ii) identify customer profit segments (e.g., Schmitt, Skiera, \& Bulte, 2011), (iii) understand customer needs, wants, benefits sought, and preferences (Barber \& Taylor, 2011), (iv) identify unmet customer needs, (v) analyze user reaction surveys and customer reviews (e.g., Lee \& Bradlow, 2011), and (vi) customer lifetime value (CLV) analysis and customer relationship management (CRM) activities (e.g., Álvarez, Casielles, \& Díaz Martín, 2011; Beverland \& Lindgreen, 2004; Blattberg, Malthouse, \& Neslin, 2009; Payne \& Frow, 2006; Pfeifer \& Carraway, 2000; Venkatesan, Kumar, \& Bohling, 2007).

\section{Employee-related activities}

Employee perceptions regarding organizational support for employee development has often influenced employee performance and consequently company turnover (Kraimer, Seibert, Wayne, Liden, \& Bravo, 2011). Thus, the widespread usage of the construct of employee motivation (e.g., Maxwell \& Knox, 2009) in academic marketing research related to firm performance led us to consider the following employee-related activities as 
Table 3. How different strategy modes fit with management activities.

\begin{tabular}{|c|c|c|c|c|c|}
\hline Specific management activities & Command & Symbolic & Rational & Transactive & Generative \\
\hline \multicolumn{6}{|l|}{ Customer-related activities } \\
\hline Understand customer profitability & $\mathrm{H}$ & $\mathrm{L}$ & $\mathrm{H}$ & $\mathrm{H}$ & L \\
\hline Identify customer profit segments & $\mathrm{H}$ & $\mathrm{L}$ & $\mathrm{H}$ & $\mathrm{H}$ & $\mathrm{L}$ \\
\hline Understand customer needs and wants & M & $\mathrm{L}$ & M & $\mathrm{H}$ & M \\
\hline Identify unmet customer needs & $\mathrm{H}$ & $\mathrm{L}$ & $\mathrm{H}$ & $\mathrm{H}$ & $\mathbf{M}$ \\
\hline User reaction surveys & $\mathrm{L}$ & $\mathrm{L}$ & M & $\mathrm{H}$ & $\mathrm{M}$ \\
\hline CLV and CRM activities & $\mathrm{L}$ & L & $L$ & $\mathrm{H}$ & M \\
\hline \multicolumn{6}{|l|}{ Employee-related activities } \\
\hline Employee training programs & $\mathrm{M}$ & $\mathrm{M}$ & $\mathrm{M}$ & $\mathrm{H}$ & $\mathrm{M}$ \\
\hline Employee satisfaction surveys & $\mathrm{L}$ & $\mathrm{M}$ & $\mathrm{L}$ & $\mathrm{H}$ & $\mathbf{M}$ \\
\hline Employee reward systems & $\mathrm{L}$ & $\mathrm{H}$ & $\mathrm{L}$ & M & $\mathrm{H}$ \\
\hline Employee loyalty programs & $\mathrm{L}$ & $\mathrm{H}$ & $\mathrm{L}$ & $\mathrm{H}$ & M \\
\hline Inspire employee achievements & $\mathrm{L}$ & $\mathrm{H}$ & $\mathrm{L}$ & $L$ & $\mathrm{H}$ \\
\hline Motivate employee creativity & $\mathrm{L}$ & M & L & $\mathrm{L}$ & $\mathrm{H}$ \\
\hline \multicolumn{6}{|l|}{ Environment-oriented activities } \\
\hline $\begin{array}{l}\text { Monitor markets and technology } \\
\text { developments }\end{array}$ & M & $\mathrm{H}$ & $\mathrm{H}$ & M & $\mathrm{H}$ \\
\hline Portfolio analysis & $\mathrm{H}$ & $\mathrm{M}$ & $\mathrm{H}$ & $\mathrm{L}$ & $\mathrm{L}$ \\
\hline Competitor analysis & $\mathbf{M}$ & $\mathbf{M}$ & $\mathbf{H}$ & $\mathrm{L}$ & $\mathbf{M}$ \\
\hline SWOT analyses & $\mathbf{M}$ & $\mathrm{L}$ & $\mathrm{H}$ & $\mathrm{L}$ & $\mathrm{M}$ \\
\hline Market segmentation studies & $\mathrm{H}$ & $\mathrm{M}$ & $\mathrm{H}$ & $\mathrm{L}$ & $\mathrm{L}$ \\
\hline Venture capital activities & $\mathrm{H}$ & $\mathrm{L}$ & $\mathrm{H}$ & $\mathrm{L}$ & $\mathrm{L}$ \\
\hline Mergers and acquisitions & $\mathrm{H}$ & & $\mathrm{L}$ & $\mathrm{L}$ & M \\
\hline \multicolumn{6}{|l|}{ Process activities } \\
\hline Operational excellence & $\mathrm{H}$ & M & $\mathrm{H}$ & M & $\mathrm{H}$ \\
\hline Basic R\&D & $\mathrm{H}$ & M & $\mathrm{H}$ & M & $\mathrm{H}$ \\
\hline Team-based innovation & $\mathrm{L}$ & $\mathrm{L}$ & $\mathrm{L}$ & M & $\mathrm{H}$ \\
\hline Brainstorming workshops & $\mathrm{L}$ & $\mathrm{M}$ & $\mathrm{L}$ & $\mathrm{L}$ & $\mathrm{H}$ \\
\hline Skunkwork & $\mathrm{L}$ & $\mathrm{L}$ & M & $\mathrm{L}$ & $\mathrm{H}$ \\
\hline Technological synergy & $\mathrm{L}$ & $\mathrm{H}$ & $\mathrm{L}$ & $\mathrm{M}$ & $\mathrm{H}$ \\
\hline Continuous, ongoing adjustments & $\mathrm{L}$ & $\mathbf{H}$ & $\mathrm{L}$ & $M$ & $\mathrm{H}$ \\
\hline $\begin{array}{l}\text { Intra-organizational conferences and } \\
\text { get togethers }\end{array}$ & $\mathrm{L}$ & $\mathrm{H}$ & Ł & $\mathrm{H}$ & $\mathrm{L}$ \\
\hline Entrepreneurial & $\mathrm{H}$ & $\mathrm{L}$ & $\mathrm{H}$ & $\mathrm{L}$ & $\mathrm{L}$ \\
\hline Quality control activities & $\mathrm{H}$ & $\mathrm{L}$ & $\mathrm{M}$ & $\mathrm{H}$ & $\mathrm{L}$ \\
\hline Quality function deployment & $\mathrm{H}$ & $\mathrm{L}$ & $\mathrm{M}$ & $\mathrm{H}$ & $\mathrm{L}$ \\
\hline $\begin{array}{l}\text { Value proposition and value chain } \\
\text { analysis }\end{array}$ & $\mathrm{H}$ & $\mathrm{H}$ & $\mathrm{M}$ & $\mathrm{M}$ & $\mathrm{L}$ \\
\hline \multicolumn{6}{|l|}{ Launch activities } \\
\hline Customization & $\mathrm{M}$ & $\mathrm{H}$ & $\mathrm{M}$ & $\mathrm{M}$ & $\mathrm{M}$ \\
\hline Innovation & $\mathrm{H}$ & $\mathrm{L}$ & $\mathrm{M}$ & $\mathrm{L}$ & $\mathrm{H}$ \\
\hline Idea generation & $\mathrm{H}$ & M & $\mathrm{H}$ & $\mathrm{L}$ & $\mathrm{H}$ \\
\hline Action plans for launch & $\mathrm{H}$ & $\mathrm{L}$ & $\mathrm{H}$ & $\mathrm{L}$ & $\mathrm{L}$ \\
\hline Differentiation & $\mathrm{L}$ & $\mathrm{M}$ & $\mathrm{L}$ & $\mathrm{H}$ & $\mathrm{H}$ \\
\hline $\begin{array}{l}\text { Launch of flanker brands and offering } \\
\text { variants }\end{array}$ & $\mathrm{L}$ & $\mathrm{M}$ & $\mathrm{L}$ & $\mathrm{H}$ & $\mathrm{M}$ \\
\hline Line management & $\mathrm{M}$ & $\mathrm{M}$ & $\mathrm{M}$ & $\mathrm{H}$ & $\mathrm{M}$ \\
\hline
\end{tabular}

Note: 'H', high degree of match; ' $M$ ', moderate degree of match; ' $L$ ', low degree of match; SWOT, Strengths, Weaknesses, Opportunities, and Threats.

key drivers for strategy-making: (i) employee training programs (e.g., Salmela-Aro, Mutanen, \& Vuori, 2012), (ii) employee satisfaction surveys or examining employee satisfaction (e.g., Futrell \& Parasuraman, 1984), (iii) employee reward systems (France, 1996; Harris \& Kleiner, 1993), (iv) employee loyalty programs, (v) inspiring employee 
achievements or employee perceptions of organizational support (Kraimer et al., 2011), and (vi) employee creativity facilitation (France, 1996; Lloyd, 1996).

\section{Environment-oriented activities}

The environment refers to the general situational context of the organization (Houston, Ratneshwar, Ricci, \& Malter, 2010; Jaworski, 1988), be it macro (national or global context; Grant \& King, 1982), operating (sets of suppliers, employees, or other interest groups the firm deals with directly; Galbraith, 1977), and/or internal (elements within the firm's official jurisdiction; Grant \& King, 1982; Jaworski, 1988). Thus, environment-oriented activities refer to activities the organization engages in order to cope with the external and internal environments, namely, monitor markets and technology developments (e.g., Kaul, 2012; Sood \& Tellis, 2005), SWOT analysis (e.g., Helms \& Nixon, 2010), competitor analysis (e.g., Chen, 1996), portfolio analyses (e.g., Day, 1977; Henderson, 1979, Homburg, Steiner, \& Totzek, 2009), market segmentation studies (e.g., Asllani \& Halstead, 201 1; O'Regan, Kalidas, Maksimova, \& Reshetin, 2011), venture capital activities (e.g., Park \& Steensma, 2012), and mergers and acquisitions (e.g., Homburg \& Bucerius, 2005; Valentini, 2012).

\section{Process activities}

The product development process typically moves through a series of stages with decision points where unsatisfactory options are screened out. Keeping in mind the various building blocks of the developmental process, in our research, we focus on the following process activities: (i) operational excellence (e.g., Asif, Fisscher, de Bruijn, \& Pagell, 2010; Holtzman, 2011), (ii) basic R\&D (e.g., Krasnikov \& Jayachandran, 2008) (iii) team-based innovation, (iv) brainstorming workshops (e.g., Edward, 1972), (v) skunkwork (e.g., Gwynne, 1997), (vi) technological synergy (e.g., Cooper \& Kleinschmidt, 1987; Rese \& Baier, 2011), (vii) continuous, ongoing adjustments, (viii) intra-organizational conferences and get-togethers, (ix) entrepreneurial (e.g., Dickson \& Giglierano, 1986; Matsuno, Mentzer, \& Ozsomer, 2002), (x) quality control activities, (xi) quality function deployment (e.g., Zeithaml \& Parasuraman, 1988), and (xii) value proposition and value chain analysis (e.g., Ailawadi, Pauwels, \& Steenkamp, 2008).

\section{Launch activities}

New product launch proficiency has often been considered crucial for market success (e.g., Langerak, Hultink, \& Robben, 2004; Talke \& Hultink, 2010). In fact, one major determinant of sustaining competitive advantage is the ability of the firm to develop and launch successful new products (Song \& Parry, 1997). Several studies have looked into a variety of activities that help product launching, for example, promotional activities (e.g., Delre, Jager, Bjjmolt, \& Janssen, 2007), experiential learning (e.g., Yeniyurt, Townsend, \& Talay, 2007), diffusion barriers (e.g., Talke \& Hultink, 2010), high quality of selling effort and technical support (Di Benedetto, 1999), and market orientation (e.g., Langerak et al., 2004). In accordance with prior literature, we consider the following relevant launch activities for the purposes of this paper: (i) customization (e.g., Franke, Keinz, \& Steger, 2009), (ii) innovation (e.g., Chandy \& Tellis, 2000; Cooper, 1979; Srinivasan et al., 2011), (iii) idea generation (e.g., von Hippel, 1978), (iv) action plans for launch, (v) differentiation (e.g., Dickson \& Ginter, 1987), (vi) launch of flanker brands and offering variants (e.g., Hume, 1992), and (vii) line management (Balachander \& Ghose, 2003). 


\section{The fit between different strategy modes and environmental characteristics}

It is to be assumed that an organization must react to environmental changes by implementing suitable strategies. Indeed, past researchers have empirically examined the proper fit or match between different strategies and the industry to which the business belongs to, the broad macro-environmental variables or environmental uncertainty (e.g., Hatten \& Schendel, 1977). Thus, in this section, we aim to identify appropriate environmental characteristics that are appropriate for successful implementation of each of Hart's strategy modes.

The command mode focuses on organizational goal-setting and carefully developed plans by top management (Mintzberg, 1973). However, successful control of the entire organizational system at the top is only possible when the marketing environment is simple (see Table 2) and relatively mature. It is not possible for a single individual or a very small group of individuals to deal with a complex environment that is marked by continuous, rapid changes. Thus, the command mode is most effective in a stable, surprise-free, fairly predictable market environment (Mintzberg \& Waters, 1985) with high entry barriers.

Proposition 1(a): The command strategy mode will fit best with the following productmarket environments: (i) less complex, predictable environments; (ii) markets with stable competition; and (iii) markets with high entry barriers.

The symbolic mode emphasizes a mission of change (Hart, 1992). Unlike the command and rational modes, the symbolic mode does not involve detailed formal planning. Some researchers have suggested that the rational view of formulating strategy does not correspond at all with reality. Murray (1978, p. 971) states, 'No longer are traditional theories of planning as a rational synoptic form of decision making sufficient.' Instead, scholars have argued in favor of continuous adjustments and improvements of the organization's current strategy in response to and in consonance with a changing environment (e.g., Sirmon, Hitt, \& Ireland, 2007). Furthermore, in order to operate effectively in such environments, it is imperative to constantly monitor developments in markets and technologies. Thus, product-markets that are growing, characterized by environmental turbulence (Bourgeois \& Eisenhardt, 1988) and increasing competition (indicative of markets with moderate entry barriers) necessitate a symbolic mode, which is more conducive to quick, radical change.

Proposition 1(b): The symbolic strategy mode will fit best with the following productmarket environments: (i) growing markets; (ii) unstable, turbulent markets; (iii) markets with increasing competition; and (iv) markets with moderate entry barriers.

A rational mode, involving detailed environmental analyses and formal planning, is time consuming and thus not conducive to rapid, continuous changes. It is more appropriate in a surprise-free, fairly predictable market environment (Mintzberg \& Waters, 1985). It should also suit capital-intensive manufacturing businesses (e.g., semiconductor chips) where the existing players in the industry are unlikely to be surprised by new entrants, thanks to the presence of formidable capital and technology barriers (Ali, 1994; Hise, O'Neal, Parasuraman, \& McNeal, 1990; Porter, 1985). Finally, a rational strategy should work well for firms that operate under the shelter of licensing and regulatory protection because such factors considerably reduce the threat of unexpected competitor moves. It is also a good strategy for defending positions in stable markets. 
Proposition 1(c): The rational strategy mode will fit best with the following productmarket environments: (i) less complex, predictable environments; (ii) markets with stable competition; (iii) markets with high entry barriers; (iv) markets with capital intensive businesses; and (v) markets with licensing and/or regulatory protection.

A transactive mode focuses more on defending market share by retaining valued customers and employees and less on developing new products. Thus, it is more appropriate for organizations that operate in mature and/or complex product-markets. This type of strategy mode is oriented toward building long-term relationships; as such, strategy execution is likely to be time consuming and not suited for rapid changes. When the market is wellestablished, competition is stable, and entry barriers are high, it makes sense to emphasize a transactive mode wherein customer and employee loyalty are the keys to profitability.

Proposition 1(d): The transactive strategy mode will fit best with the following product-market environments: (i) mature markets; (ii) complex environments; and (iii) high customer bargaining power.

Finally, a generative mode is one where top management is willing to modify and adjust strategy based on innovative ideas emerging bottom-up in the organization. It thus lacks the deliberate control and plan of a command or a rational strategy mode (Houston et al., 2010), but provides the rapid adaptation capability of a symbolic mode making it similarly appropriate for markets with environmental turbulence. Hence, a generative strategy mode is facilitated by specific organization characteristics such as a decentralized structure, a learning mindset (Dickson, Farris, \& Verbeke, 2001; Mintzberg, 1987), and a bottom-up decision-making style. Such a strategy is well suited for fragmented, complex, and fast-changing environments and unstable markets (Løwendahl \& Revang, 1998).

Propositions 1(e): The generative strategy mode will fit best with the following product-market environments: (i) unstable markets; (ii) markets with complex, fragmented environments; and (iii) markets with environmental turbulence.

As evidenced by the various propositions stated above, the five strategy modes are not mutually exclusive in their appropriateness to different characteristics of product-markets. That is, different modes could be appropriate for similar environments, and more importantly, combinations of strategy could have significant value in responding to specific product-market environments. Accordingly, we later explore the relevance and value of combining various strategy modes with regards to different stages of the productmarket life cycle.

\section{The fit between different strategy modes and management activities}

Successful strategy implementation depends upon a fit between the strategy and the internal characteristics of the business (Walker \& Ruekert, 1987). Thus, in this section, we attempt to identify management activities of the business that are appropriate and suitable in the context of each of Hart's strategy modes.

First, the systematic nature of the command strategy mode, emphasizing careful planning, makes it appropriate for launching really new products (Zirger \& Maidique, 1990), including process, environment-oriented, product launch, and customer-related activities. The marketing literature on product development emphasizes step-by-step 
processes starting with a solid understanding of customer and market needs and all the way through product commercialization (e.g., Urban \& Hauser, 1993). Thus, deliberate control by the top management makes this strategy mode ideal for a systematic product development process and, consequently, ideal for process activities (see Table 3) such as operational excellence, quality control, value chain analysis, supply chain analysis, etc. The command mode also enables focus on environment-oriented activities such as market segmentation studies, portfolio analysis, etc. The top-down, proactive nature of this mode is also well suited for organizations that wish to periodically initiate radical change in their product lines or even in how their businesses are defined. A command strategy is therefore consistent with resource allocations to basic R\&D activities that might afford major technology breakthroughs or radical innovations in immature markets. Such a strategy is also appropriate for small, venture-capital funded enterprises (e.g., in the biotechnology industry) that spend many years in developing products at the frontiers of technology. In addition, the strategic nature of the command mode aligns itself with several launch (e.g., generating new product ideas and innovation) and customer-related activities (e.g., identifying unexplored customer needs and profitable market segments).

Proposition 2(a): The command strategy mode will be most effective for carrying out the following product-market activities: (i) process activities such as operational excellence and quality control; (ii) environment-oriented activities such as market segmentation studies and venture capital activities; (iii) launch activities such as product idea generation; and (iv) customer-related activities such as identifying unmet customer needs.

Second, process- and employee-related activities are the two main product-market activities consistent with a symbolic mode. A few environment-oriented and product launch activities are also suitable. As mentioned before, the main objective of the symbolic mode is to embed all organizational members with a strong feeling of belongingness that will lead to true commitment towards attaining the organization's vision (Hart, 1992). In order to create this strong sense of identity for the employees, cross-departmental employee interaction should be encouraged (Dutton \& Dukerich, 1991). Employees should be inspired by continuous rewards and encouragement (employee-related activities, see Table 3). Consequent employee involvement should help get a better perspective of the products and services offered leading to enhanced product and service customization (product launch activities).

The symbolic mode implicitly stresses continuous adjustments and improvements of the organization's current strategy in response to, and in consonance with, a changing environment. Such an approach should be facilitated by environment-oriented activities, including constant monitoring of the market and technological developments. The symbolic mode's emphasis on change and flexibility is further reinforced by process activities (see Table 3) such as technological synergy, supply chain management activities, value chain activities, and just-in-time management activities.

Proposition 2(b): The symbolic strategy mode will be most effective for carrying out the following product-market activities: (i) employee-related activities such as employee reward systems and employee loyalty programs; (ii) process activities such as technological synergy and value chain analysis; (iii) launch activities such as product 
customization; and (iv) environment-oriented activities such as monitoring markets and technology development.

The rational mode, with its focus on logic and comprehensiveness in strategy development (Fredrickson, 1983), is consistent with strategy approaches that emphasize mission statements and business plan development (Covin, Slevin, Schultz, \& Randall, 1994; Weitz \& Wensley, 1984); it is thus most appropriate for conducting a variety of process and environment-oriented activities. Rational decision making by management (Andrews, 1971; Ansoff, 1965) is often equated with the consciously controlled thought processes of a corporate 'strategist' (Tadepalli \& Avila, 1999). Like the command mode, the systematic nature of this strategy should make it an appropriate mode to design and launch new products (Zirger \& Maidique, 1990) starting with a solid understanding of customer and market needs and all the way through product commercialization (e.g., Urban \& Hauser, 1993). Brown and Eisenhardt (1995) review a number of published studies in the management literature and conclude that successful product development is the result of excellent internal organization, rational planning, and strong execution. Again, like the command mode, a rational strategy, should yield superior performance in process activities such as basic R\&D activities and operational excellence. However, unlike the command mode, this mode emphasizes environmental scanning that involves a lot of information exchanges between the external and the internal environment. Thus, in contrast to the single-minded focus that often characterizes a command mode, a rational mode more consciously attempts to strike a balance between environmental risks and opportunities on one hand and organizational capabilities on the other (Chaffee, 1985; Ratneshwar et al., 1999). This can be achieved through a variety of environment-oriented activities such as SWOT analysis, portfolio analysis, market segmentation studies, competitor analysis, etc. (see Table 3). In addition, such a mode is also effective for a few customer-related (e.g., identifying unexplored customer needs and segments) and launch activities.

Proposition 2(c): The rational strategy mode will be most effective for carrying out the following product-market activities: (i) environment-oriented activities such as SWOT analysis, portfolio analysis, market monitoring and technology development, and competitor analysis; (ii) process activities such as basic R\&D and operational excellence; (iii) customer-related activities such as understanding customer profitability; and (iv) launch activities such as action plans for launching new products.

The transactive mode is 'people' oriented, especially in regard to customers and employees, thus making it best suited for customer-related and employee-related activities. Once a firm has achieved a good market position, maintenance of a product line's success typically requires the organization to develop long-term relationships with customers. In fact, past research showed how a firm's intangible assets and capabilities are crucial determinants for performance (Galbreath \& Galvin, 2008). A focus on customers helps create an emphasis on understanding customer profitability and on identifying the unmet needs of customers. This in turn leads to more product and service customization (customer-related activities, see Table 3). Similarly, developing loyalty programs should help organizations understand the cost of acquiring new customers versus the loss of profits in the case of lost customers (Reinartz \& Kumar, 2002).

In addition, high-performing employees (e.g., salespersons handling key accounts) often hold the key to customer satisfaction and loyalty (Michlitsch, 2000). Retention of the 
right employees and customers becomes the key to defending market share and sustaining a 'cash cow.' Keeping employees happy should be facilitated through employee training systems, appropriate reward systems, and satisfaction surveys (employee-related activities, see Table 3). Competitors may try to lure away both valuable employees and profitable customers; such moves have to be countered by strengthening ties with both of these constituencies (Løwendahl \& Revang, 1998).

Furthermore, effective use of a transactive mode requires that the organization pay close attention to business fundamentals and day-to-day operations (Treacy \& Wiersema, 1993). The emphasis falls on few process activities such as quality control and quality function deployment activities (see Table 3 ), specifically to maintain close monitoring of customer satisfaction levels, cost-efficient supply chain management, and continuous quality improvements. Product innovation tends to be relatively de-emphasized, even though product and service offerings may be customized in minor ways for select buyers as a way of retaining their loyalty (especially via a few launch activities such as differentiation, launch of flanker brands, and line management).

Proposition 2(d): The transactive strategy mode will be most effective for carrying out the following product-market activities: (i) customer-related activities such as understanding customer needs and wants, user reaction surveys, and CRM activities; (ii) employee-related activities such as employee training programs, employee satisfaction surveys, employee loyalty programs; (iii) process activities such as quality control activities and quality function deployment; and (iv) launch activities such as product line management and launch of flanker brands.

Finally, generative strategy mode is best suited for a majority of employee-related and process activities. This is mainly because the generative mode mainly focuses on engendering new ideas from the organization's employees. This is usually done in conjunction with systematic processes for screening the desirability and feasibility of those ideas (Hart, 1992). Thus, with a generative mode, the organization strives to motivate and inspire employees to come up with product innovations (employee-related activities, see Table 3). This is particularly true when organizations seek sales and market share growth through continuous modifications and improvements of existing product lines rather than entirely new offerings. Constant and close monitoring of ongoing market trends (e.g., brand attitudes and purchase data) and competitors' moves help organizations to spot numerous, albeit often minor, product-market opportunities (Dickson, 1992; Ratneshwar et al., 1999). Market research studies (environment-oriented activities, see Table 3) that assess users' reactions of current products and market segmentation are also important information tools for adapting existing product lines.

The generative mode is recommended when markets are characterized by high competitive turbulence. In such environments, unexpected external events tend to weaken the effectiveness of the extensive planning that is characteristic of a command or a rational strategy mode (Eisenhardt \& Tabrizi, 1995). During high market turbulence, there is a greater need for improvisation in product development (Moorman \& Miner, 1998). Furthermore, 'on-the-fly' improvisation and speedy response necessitate frequent experimentation and an adaptive approach rather than the carefully pre-planned decisions; this would be facilitated by process activities like team-based innovation, focus groups, operational excellence, brainstorming workshops, etc. along with some environmentoriented activities like monitoring market and technology developments (see Table 3). 
Consistent with the idea of in-house brainstorming, some of the launch activities are also appropriate for such a mode (e.g., generating new product ideas and innovating).

Proposition 2(e): The generative strategy mode will be most effective for carrying out the following product-market activities: (i) employee-related activities such as employee reward systems, inspiring employee achievement, employee creativity motivational activities; (ii) process activities such as team-based innovation, focus groups, generation of creativity workshops, skunkwork, and just-in-time activities; (iii) environment-oriented activities such as monitoring markets and technology development; and (iv) launch activities related to product innovation and product differentiation.

We now build on the ideas discussed above by examining the appropriateness of the various strategy modes for different stages of the product-market life cycle.

\section{Strategy modes and different stages in the product-market life cycle}

Few management concepts have been so thoroughly accepted or criticized as the PLC. Marketers in the past have reached a consensus that the evolution of product markets reflects the outcome of many market, technological, and competitive forces, determining the rate of sales growth or decline over PLC (Lambkin \& Day, 1989). The notion of unique stages with distinct sets of threats and opportunities with regards to profit making (Kotler, 1980) makes PLC considerations crucial to strategy-making. In fact, prior research has identified PLC as a guiding framework for adapting strategies with varying marketing conditions (Kotler, 1984), and the PLC framework has been considered as the most fundamental variable in determining an appropriate business strategy.

Due to the normative nature of the PLC, numerous researchers have postulated appropriate strategies for each of the stages (e.g., Rink \& Swan, 1979) or a fit between strategies and PLC stages (e.g., Anderson \& Zeithaml, 1984). However, prior research has criticized generalized prescriptions of strategy for each stage of the PLC (Day, 1981). We do believe that Hart's strategy modes recognize the diversity of resources and skills among the business population and differences in the order of entries in a variety of product markets. We propose combinations of Hart's strategy modes for each life cycle stage, arguing that they should enable the PLC framework to encompass competitive processes involved in today's evolutionary markets.

First, different stages of the product-market life cycle (life cycle or PLC, for short) are characterized by specific environmental characteristics (Day, 1981). Similarly, the firm's success at different stages of the life cycle depends upon its effectiveness in carrying out specific management activities (e.g., Rink, Roden, \& Fox, 1999; Thietart \& Vivas, 1984). Therefore, based on the analysis in the preceding section, it should be possible to relate the different life-cycle stages to the strategy modes that are likely to be most appropriate for those particular stages. As mentioned above, our paper is based on the concept of combining strategy modes. Note that as combining strategic modes could lead to better market performance, Hart (1992) called for a greater understanding into the manner in which organizations might need to combine strategic modes to best suit the situation facing the organization. Consequently, Hart and Banbury (1994) explored the relationship between different combinations of strategy-making processes and firm performance. They did not, however, explore the concept of combinatory modes in the context of productmarket life cycles. Accordingly, we build on our preceding analysis and Hart's (1992) 
framework by examining the correspondence between specific stages of the life cycle and synergistic strategy mode combinations that are appropriate. In examining the life cycle, we focus on the introductory to early growth stage, growth stage, and mature stage as early growth stage is closer to the introductory stage of product-markets in terms of similarities concerning environmental characteristics and managerial activities. The results of our analysis are summarized and illustrated with detailed examples in Table 4.

Note that for present purposes, each strategy mode essentially defines strategic tendencies within the organization and does not necessarily describe all organizational activities. Pragmatically speaking, we assume most strategy modes are present at least to some extent in most organizations, although a few modes can be relatively more dominant.

\section{Introductory to early growth stage of the product-market life cycle}

The introductory stage of the life cycle is characterized by immature, simple, and predictable markets. Accordingly, the command mode should be most suitable for product-markets in the introduction phase, when the environment is not complex (Mintzberg \& Waters, 1985), with stable competition, mainly because of the high entry barriers. Utilizing the command mode, top management should be able to analyze alternative courses of action (Vesper, 1980) and control for necessary resource allocation decisions. It should also help top management to systematically first initiate organizational goal setting and product development plans (Mintzberg, 1973) and then supervise the design, manufacturing, and implementation details associated with the introduction stage.

In addition, organizations in the introductory phase need to formally and systematically scan the external and internal environment to come up with new products or radical innovations (Moorman \& Miner, 1998). In this regard, past research shows that sales and profit-related performance is correlated with heavy research and development orientation and spending (Cooper, 1985). The rational strategic mode is consistent with thorough, structured market research for determining appropriate marketing mix variables and market education tactics. Such a mode, which emphasizes both external and internal data processing (Miller, 1989), should be able to balance organizational skills with unmet customer needs in order to exploit unexplored market opportunities. It also affords a careful analysis of market entry and timing decisions such as when and how to enter the market. Thus, the rational mode should help organizations create product launch objectives, build a framework to carry out these objectives, and design as well as coordinate necessary internal processes accordingly (Urban \& Hauser, 1993). In order to minimize confusion and maximize coordination, the planning process associated with a rational strategy should be quite detailed and elaborate (Mintzberg \& Waters, 1985; Wood \& Laforge, 1979). Again, the rational mode is ideal for proactive new product introduction on the part of product pioneers, specifically in an environment of formidable capital and technology barriers (Ali, 1994; Hise et al., 1990; Porter, 1985).

Given the above assessment, both the command and rational modes should be effective for carrying out product-market activities in the introductory phase of the life cycle. Both emphasize formal planning and analyses appropriate for launching a new product in the market and are best suited in a simple, uncomplicated, and predictable market environment (see Tables 2 and 3). The command mode, with its focus on complete control by the top management over the firm's activities, should be well balanced by the rational mode which emphasizes environmental scanning and information processing. Productmarkets in the introduction and early growth phase initially require a lot of formal planning and analyses (rational), followed by constant scrutiny and guidance during the execution 
Table 4. Product-market life cycle stages and combinatory strategy modes: illustrative examples.

\begin{tabular}{|c|c|c|c|c|}
\hline $\begin{array}{l}\text { Exemplar } \\
\text { product-market }\end{array}$ & $\begin{array}{l}\text { Life cycle } \\
\text { stage }\end{array}$ & Characteristics & Firms are required to: & $\begin{array}{l}\text { Therefore, firms could benefit } \\
\text { from combining the: }\end{array}$ \\
\hline $\begin{array}{l}\text { Biogenetic } \\
\text { engineering } \\
\text { product-market }\end{array}$ & $\begin{array}{l}\text { Introduction } \\
\text { and early } \\
\text { growth stage }\end{array}$ & $\begin{array}{l}\text { - Few competitors } \\
\text { - Majority of products are based on } \\
\text { breakthrough technology } \\
\text { - Immature market } \\
\text { - Immense growth potential } \\
\text { - Lack of environmental turbulence }\end{array}$ & $\begin{array}{l}\text { - Introduce innovative products } \\
\text { - Emphasize market research that } \\
\text { helps monitor diverse market } \\
\text { conditions } \\
\text { - Create advertising to stimulate } \\
\text { demand } \\
\text { - Use premium prices to balance } \\
\text { R\&D and promotional invest- } \\
\text { ments } \\
\text { - Educate customers } \\
\text { - Make use of aggressive marketing } \\
\text { strategies }\end{array}$ & $\begin{array}{l}\text { Environmental scanning and } \\
\text { systematic planning offered by the } \\
\text { rational mode with the incessant } \\
\text { scrutinizing provided by the } \\
\text { command mode }\end{array}$ \\
\hline $\begin{array}{l}\text { Personal } \\
\text { computer } \\
\text { product-market }\end{array}$ & $\begin{array}{l}\text { Late growth } \\
\text { stage }\end{array}$ & $\begin{array}{l}\text { - Intense competition } \\
\text { - Firms constantly come up with } \\
\text { new upgrades } \\
\text { - Continuous supply of new, } \\
\text { innovative versions } \\
\text { - Knowledgeable customers }\end{array}$ & $\begin{array}{l}\text { - Fine-tune offerings based on } \\
\text { customer response to their offer- } \\
\text { ings, competitor challenges, and } \\
\text { new technological developments } \\
\text { - Monitor market conditions closely } \\
\text { and spot market segments and } \\
\text { niches as they become identifiable } \\
\text { - Update (or re-price) and introduce } \\
\text { major product variants based on } \\
\text { user feedback, and/or competi- } \\
\text { tors' moves }\end{array}$ & $\begin{array}{l}\text { Symbolic mode's motivation to } \\
\text { change with the generative mode's } \\
\text { rapid adaptations in high-speed } \\
\text { environments }\end{array}$ \\
\hline $\begin{array}{l}\text { Defined benefit } \\
\text { retirement } \\
\text { services } \\
\text { product-market }\end{array}$ & $\begin{array}{l}\text { Maturity } \\
\text { stage }\end{array}$ & $\begin{array}{l}\text { - Little product innovation } \\
\text { - Steadily declining use of the } \\
\text { offerings to customers } \\
\text { - Little competitive turbulence } \\
\text { - Relatively stable market segments }\end{array}$ & $\begin{array}{l}\text { - Focus on defending their current } \\
\text { market positions } \\
\text { - Milk their cash cow products } \\
\text { - Take an 'incremental' approach to } \\
\text { strategy-making }\end{array}$ & $\begin{array}{l}\text { Humanistic approach (transactive), } \\
\text { rapid product and service adjust- } \\
\text { ments through employee innovative } \\
\text { behavior (generative), and the } \\
\text { sincerity provided by committed } \\
\text { employees (symbolic mode) }\end{array}$ \\
\hline
\end{tabular}


process (command). Thus, a combination of the command and rational modes should be most effective for the introductory stage and also for the early growth stage of the life cycle.

Proposition 3(a): A combination of rational and command strategy modes is most appropriate for the introduction and early growth stages of the product-market life cycle.

\section{Growth stage of the product-market lifecycle}

Product-markets in the growth stage often face uncertainties because of changing market conditions. In order to adapt and improvise strategy to address opportunities and threats in such growing, technologically uncertain markets, organizations require considerable strategic flexibility (Aaker \& Mascarenhas, 1984; Bowman \& Hurry, 1993). Strategic flexibility refers to an organization's ability to respond in a proactive or reactive manner to market threats and opportunities and also to engage in 'surprise management' (Ansoff, 1980). According to Grewal and Tansuhaj (2001), higher levels of strategic flexibility will lead to higher levels of firm performance after crisis. Also, Rudd, Greenley, Beatson, and Lings (2008) show how strategic flexibility mediates the relationship between strategic planning and performance relationship.

Hart (1992) points out that a symbolic mode is most appropriate for rapidly growing firms in environments characterized by rapid change. This mode creates a mission and motivation for change including constant monitoring of the market and technological developments (see Table 3). Such an approach enables organizations to survive in hostile industries (Dess \& Beard, 1984), especially those marked by increasing numbers of competitors and competitive activity. Moreover, quick changes in product and service offerings often have to be made in highly dynamic environments (Bourgeois \& Eisenhardt, 1988). Thus, the symbolic mode is likely to provide the necessary speed (e.g., value chain activities and just-in-time management activities; see Table 3) and flexibility required for a competitive edge in product-markets in the late growth stage.

In addition to the symbolic mode, the generative mode also merits consideration for this stage of the life cycle. The latter mode emphasizes bottom-up decision-making, where the informational inputs and action initiatives emerging from lower levels of the organization are likely to get the necessary support, in a timely fashion, from higher levels of management (see Table 3). Such a decentralized decision-making structure and a learning mindset (Dickson et al., 2001; Mintzberg, 1987), involving market research activities (see Table 3), help rapid adaptation in fast-changing environments (Løwendahl \& Revang, 1998). In fact, it has been seen that companies facing turbulent environment emphasize decentralization in order to develop faster strategic market plans (Silverblatt \& Korgaonkar, 1987). Also, recently, Bridges and Freytag (2009) examine how firms do a lot of employee engagement activities (e.g., engage in sharing information with the employees, rewarding them for new ideas, etc.) in a market with high competitive intensity. Thus, the generative mode is also appropriate for turbulent, complex (Emery \& Trist, 1965; Hart, 1992; see Table 2), and fragmented (Miles \& Snow, 1978) environments, such as those prevalent in the growth stage of the life cycle.

Finally, the generative mode is conducive to top management being receptive to innovative ideas from employees, with the firm acting as an intrapreneurship venture. Also, the symbolic mode with a corporate mission for change is effective in a proactive environment. Thus, a combination of both would result in a strong corporate mission to change (symbolic) based on innovative activities of the organizational members 
(generative), especially when there is no time to be lost in formal planning and analyses. Therefore, a combination of the symbolic and generative modes is most appropriate for product-markets in the growth stage.

Proposition 3(b): A combination of symbolic and generative strategy modes is most appropriate for the growth stage of the product-market life cycle.

\section{Mature stage of the product market life cycle}

For firms that operate in mature product-markets, the strategic focus has to shift to promotion of social contracts and ties, both within the organization and between the organization and its customers. At this stage of the PLC, traditional theories of planning, which emphasize a rational, linear manner of decision-making are inadequate (Murray, 1978). In order to achieve success, an organization should not only try to satisfy customers, but also other members associated with the organization's external coalition (labor, government, financial institutions, and investors). According to Slater and Olson (2001), such organizations, being 'defenders' of their product markets, should use a value marketing strategy, providing superior performance and excellent service to customers at an appealing price point. Consequently, employees who are vital for maintaining customer relationships are key assets of the organization because they may be able to prevent customers from switching to competitors. In fact, prior research has demonstrated that companies emphasizing employee motivation and retention and maintenance of valued customer relationships in mature businesses have better financial results than companies who do not (Michlitsch, 2000).

Within this context, a humanistic, relational approach, characterized by open and amiable communications, becomes preferable to systematic planning or speedy response to technological changes and product-market structure. Accordingly, the transactive strategic mode which emphasizes cross functional communications and negotiations (rather than planned execution) (Fiol \& Lyles, 1985) may be best suited for mature markets. Ongoing dialog with the customers (i.e., developing long-term relationships with customers; see Table 3) not only helps in image-management activities, but also helps to analyze user reactions and identify customer profit segments, leading to product customization and product line management. Furthermore, lateral communication with the employees also makes it possible to understand employee motivations, the result being satisfied, rewarded, and motivated employees (via employee training systems, appropriate reward systems, and satisfaction surveys, etc.; see Table 3), who are well suited for a mature product-market.

Product customization or service enhancements in minor ways with a focus on relational benefits may help the product market at this point of time; that is, the existing product concept needs to be refreshed or redefined. This requires a strategy with structural flexibility and empowered employees able to cater to the needs of the individual customers. Given this, the generative strategic mode that aims to reward employees and engender greater involvement on their part, is also appropriate for mature markets. The main objective of this mode is to encourage innovative ideas by employees (Mintzberg \& McHugh, 1985); for this reason, creative behavior by employees which allows for quick, ad hoc solutions and improved customer interactions is constantly encouraged.

As a third component to this strategic combination of modes, the symbolic mode focuses on creating a strong sense of identity for the employees (via cross-departmental employee interaction, continuous rewards and encouragements, etc.; see Table 3) to improve their commitment. As with the generative mode, the symbolic mode strives 
toward maintaining good employee relationships through increased satisfaction, organization-sponsored social events, and effective reward programs meant to create a strong sense of loyalty among employees, and subsequently, brand loyal, satisfied customers. Hence, the symbolic mode is also appropriate for product-markets in mature phase when customer relationship management becomes very crucial.

As with the previous two strategy mode combinations, this combinatory mode should be preferable to a singular mode. Although the transactive mode represents the most appropriate strategy for product markets in the maturity phase, it is counterbalanced by the benefits created through the generative and symbolic modes. Hart's (1992) transactive mode deals with cross-functional communication and helps product-markets to understand more about consumer needs, shareholder concerns, etc. Thus, such an approach improves relationship management. However, this ongoing dialog with customers, shareholders, and relevant others is quite time consuming. In contrast, the generative mode, which focuses on creative, innovative employee behavior, can quicken organizational response to customer concerns. Additionally, the symbolic mode enhances employee motivation and commitment by creating a strong sense of identity for the employees. Understanding employee needs and providing them with more care and power helps to improve employee negotiation and communication with the consumers, ultimately leading to enhanced customer relations. Thus, a combination of these three modes would be best for mature product markets. Such a combinatory approach would not only create a strong sense of identity for the employees (symbolic) thereby enhancing their motivation and commitment, but also ongoing dialog (transactive), followed by innovative employee behavior (generative), all promote a greater understanding of how to answer customer concerns in a superior manner.

Proposition 3(c): A combination of symbolic, transactive, and generative strategy modes is most appropriate for the maturity stage of the productmarket life cycle.

In summary, in the context of product-market life cycles, we propose that firms should employ a combination of strategy modes at a single point in time based on the stage of the product-market life cycle. This is possible if the combinations are of strategic modes with reasonably similar foci, supporting similar product-market environments and activities. Also, a single strategy mode may be appropriate for more than one lifecycle stage. For example, the generative mode may be best for late growth stage; however, it can be used in combination with a transactive mode during the late maturity stage as well. Thus, we envisage the use of different combinatory modes by firms competing in different stages of the product-market life cycle. We acknowledge that there may be significant difficulties in utilizing multiple, distinct strategic modes. There are obvious obstacles to consider such as goal prioritization, resource commitment, efficacy of managers, etc. However, we believe that the benefits derived from combining strategy modes far outweigh the potential difficulties. In order to effectively and efficiently use combined strategy modes, firms must carefully consider their internal resources and the extemal product-market environments.

\section{Discussion}

There is a dearth of research with reference to environmental influences in the context of strategy (Shipp \& Lamb, 1996). Building on Hart's (1992) work as well as more recent research in management and marketing, we examined the appropriateness of five strategymaking modes (command, symbolic, rational, transactive, and generative) to 
environmental characteristics, management activities, and different stages of the life cycle from a product-market perspective. Our paper makes five specific contributions to research on strategy modes. First, building on the tradition of research at the intersection of marketing and management disciplines for mutually beneficial, rich insights, this is the first paper to explore strategy modes in the context of marketing environments, including the product-market life cycle. Second, based on a discussion of ideal market and organizational characteristics for the five modes of strategy, this paper probes the appropriateness of each strategy mode for effectively carrying out specific product-market activities. Third, combining our discussion of strategy modes and their appropriateness for specific product-market activities, this paper ties different strategy modes to different stages of product-market life cycle at the level of an organization or a management team that is primarily concerned with a single product line that competes in a particular productmarket. Fourth, this paper is the first to explicitly introduce and explore the concept of combining strategy modes for different stages of the product-market life cycle. Fifth, this paper presents and discusses various propositions and summary tables that relate to Hart's strategy modes, how different strategy modes fit with environmental characteristics, management activities, and the appropriateness of combinatory strategy modes for different product-market life cycle stages, including illustrative examples. These propositions and tables can be especially helpful, as a starting point, to (i) practitioners for understanding and using the strategy modes based on different situations and contexts facing the firm, and (ii) academics for further research in terms of propositional inventories and hypotheses that can be empirically tested.

Clearly, the propositions developed in this paper and much of the content presented in the tables should be subjected to further conceptual and empirical scrutiny and we call on and welcome future research efforts that build on and/or supplant our work. Future work could also link the present framework to the work of Menon, Bharadwaj, Adidam, and Edison (1999) and Slotegraaf and Dickson (2004) by exploring marketing strategy-making in terms of interconnected activities, processes, and routines. More specifically, it should be noted that the unique combinations of product market characteristics and activities we have proposed for each of Hart's strategy modes are consistent with Menon et al.'s (1999) model of strategy-making. The marketing strategy making (MSM) model proposed by Menon et al. (1999) comprises of seven underlying processes for strategy-making: situational analyses, comprehensiveness, emphasis on marketing assets and capabilities, cross-functional integration, communication quality, strategy consensus commitment, and strategy resource commitment. Hart's (1992) framework, which is based on the roles of top managers and organizational members in strategy-making processes, implies that the strategy modes could influence the aforementioned processes for marketing strategymaking. For example, situational analyses and comprehensiveness could be influenced by the command and/or rational modes, communication quality could be influenced by the symbolic mode, and cross-functional integration could be influenced by the generative mode. Also, arguably, the MSM model, with its seven underlying processes, may be too complex for most organizations to implement in totality at any one point of time. For example, a strategy mode in a mature, stable market may not need equal emphasis on situational analyses and cross-functional integration. On the other hand, depending upon product-market characteristics and activities, the proposed combinations of Hart's strategy modes could enable organizations to prioritize the processes in the MSM model leading to more efficient use of resources.

In the space of this paper, we have not been able to address many related issues. For example, despite the best intentions of their leaders, many organizations may be unable to 
switch tracks and transform their ongoing strategy modes when the product-market evolves into the next phase. Organizational, cultural, and political factors, as well as sheer complacency or inertia, could slow down the change from one strategy mode to another (Dickson, 1992). Furthermore, the feasibility of simultaneously adopting different strategic modes, even ones with similar characteristics, across different SBUs within the same firm, or even across different product management teams within the same SBU, remain quite unexplored at present. The present research has also not explored fully the relationship between employing different strategy modes, individually and in combination, with strategic goal-setting processes in organizations (Houston et al., 2010).

Despite these and other potential limitations, we believe the concept of strategy modes and the idea of combining strategy modes show a lot of promise. Our exposition should help managers appreciate the contextual appropriateness of different modes of strategic thinking and also provide useful ways to approach strategic choices. Our framework affords a greater understanding of specific situations where an organization would do well to use a combinatory strategic approach rather than a single mode approach. As noted earlier, future research could empirically test the propositional inventory that can be developed from the present tables. For example, the influence of combined strategy modes on performance measures such as market share, profits, sales, payback periods, and costs (see Anderson, Fornell, \& Lehmann, 1994; Montoya-Weiss \& Calantone, 1994) can be investigated. Also, by examining the profitability of organizations with different strategy mode combinations, while controlling for the stage of the PLC (e.g., command and rational vs. command and transactive for the introduction phase), it may be possible to determine which combination in fact yields better financial performance in a specific product-market generation. Future research could also look into the feasibility of organizations engaging in synergistic activities for different strategy modes. For example, in the case of the introductory stage of the PLC, a combinatory approach of command and rational strategy mode may help emphasize not only market monitoring and competitor analyses (rational) but also supply chain management and value chain activities (command), while a combinatory approach of symbolic and generative mode in mature phase of product markets can in parallel emphasize customer life time value and CRM activities and team-based innovations.

The idea of combining complimentary strategic modes may also be extended beyond organizational borders. As organizations move increasingly into inter-organizational relationships such as strategic alliances, the need for effective strategic formulation that incorporates elements/parties outside one firm's borders becomes ever more important. Incorporating the use of strategy mode combinations related to the product-market life cycle, such as those we have delineated here, could increase an alliance's overall sustainable competitive advantage and also pose intriguing research questions. For instance, if two organizations are considering an alliance in order to create bioengineering products, is it necessary for both organizations to adopt a command and rational mode of thought or might each organization adopt the strategic mode which best aligns with the organization's culture? Moreover, as a product moves into the next stage of the life cycle, should alliance partners consider altering their current strategy modes, and if so, in what way?

In conclusion, our integrative exploration of the interface of strategy-making processes and product-market contexts provides fertile ground for future theory development as well as empirical research. Our work also provides specific pointers for how organizations should go about the process of formulating strategy based on specific environments, desirable management activities, and product-market lifecycle stages. 


\section{References}

Aaker, D. A., \& Mascarenhas, B. (1984). The need for strategic flexibility. The Journal of Business Strategy, 5, 74-82.

Ailawadi, K. L., Pauwels, K., \& Steenkamp, J. E. M. (2008). Private label use and store loyalty. Journal of Marketing, 72, 19-30.

Ali, A. (1994). Pioneering versus incremental innovation: Review and research propositions. The Journal of Product Innovation Management, 11, 46-61.

Allison, G. T. (1971). Essence of decision: Explaining the Cuban missile crisis. Boston: Little Brown.

Álvarez, L., Caseilles, R., \& Diaz-Martin, A. (2011). Analysis of the role of complaint management in the context of relationship marketing. Journal of Marketing Management, 27, 143-164.

Anderson, C., \& Zeithaml, C. P. (1984). Stage of the product life cycle, business strategy, and business performance. Academy of Management Journal, 27, 5-24.

Anderson, E. W., Fomell, C., \& Lehmann, D. R. (1994). Customer satisfaction, market share, and profitability: Findings from Sweden. Joumal of Marketing, 58, 53-66.

Andrews, K. R. (1971). The concept of corporate strategy. Homewood, IL: Richard D. Irwin.

Ansoff, I. H. (1965). Corporate strategy. New York, NY: McGraw-Hill.

Ansoff, I. H. (1980). Strategic issue management. Strategic Management Journal, 1, 131-148.

Asif, M., Fisscher, O. A. M., de Bruijn, E. J., \& Pagell, M. (2010). Integration of management systems: A methodology for operational excellence and strategic flexibility. Operations Management Research, 3, 146-160.

Asllani, A., \& Halstead, D. (2011). Using RFM data to optimize direct marketing campaigns: A linear programming approach. Academy of Marketing Studies Journal, 15, 59-76.

Balachander, S., \& Ghose, S. (2003). Reciprocal spillover effects: A strategic benefit of brand extensions. Joumal of Marketing, 67, 4-13.

Barber, N., \& Taylor, C. (2011). Equity benefits of smaller wine regions and lifestyle segmentation. Journal of Brand Management, 19, 158-173.

Beverland, M., \& Lindgreen, A. (2004). Relationship use and market dynamism: A model of relationship evolution. Journal of Marketing Management, 20, 825-858.

Blattberg, R. C., Malthouse, E. C., \& Neslin, S. A. (2009). Customer lifetime value: Empirical generalizations and some conceptual questions. Journal of Interactive Marketing, 23, 157-168.

Bourgeois, L. J., \& Eisenhardt, K. M. (1988). Strategic decision processes in high velocity environments: Four cases in the microcomputer industry. Management Science, 14, 816-835.

Bowman, E. H., \& Hurry, D. (1993). Strategy through the option lens: An integrated view of resource investments and the incremental-choice process. Academy of Management Review, 18, $760-782$.

Bridges, E., \& Freytag, P. V. (2009). When do firms invest in offensive and/or defensive marketing? Joumal of Business Research, 62, 745-749.

Brown, S. L., \& Eisenhardt, K. M. (1995). Product development: Past research, present findings, and future direction. Academy of Management Review, 20, 343-378.

Calantone, R. J., di Benedetto, A. C., \& Bhoovaraghavan, S. (1994). Examining the relationship between degree of innovation and new product success. Journal of Business Research, 30, $143-148$.

Chandler, A. D. Jr. (1962). Strategy and structure. Cambridge, MA: MIT Press.

Chaffee, E. E. (1985). Three models of strategy. Academy of Management Review, 10, 89-98.

Chen, M. J. (1996). Competitor analysis and interfirm rivalry: Toward a theoretical integration. Academy of Management Review, 21, 100-134.

Cooper, R. G. (1979). The dimensions of industrial new product success and failure. Journal of Marketing, 43, 93-103.

Cooper, R. G. (1985). Industrial firms' new product strategies. Joumal of Business Research, 13, $107-121$.

Cooper, R. G., \& Kleinschmidt, E. J. (1987). New products: What separates winners from losers? Joumal of Product Innovation Management, 4, 169-184.

Chandy, R., \& Tellis, G. (2000). The incumbent's curse? Incumbency, size and radical product innovation. Journal of Marketing, 64(July), 1-17.

Covin, J., Slevin, G., Schultz, D. P., \& Randall, L. (1994). Implementing strategic missions: Effective strategic, structural and tactical choices. The Journal of Management Studies, 31, $481-505$. 
Day, G. S. (1977): Diagnosing the product portfolio. Joumal of Marketing, 41, 29-38.

Day, G. S. (1981). The product life cycle: Analysis and applications issues. Journal of Marketing, 45, 60-67.

Day, G. S., Shocker, A. D., \& Srivastava, R. K. (1979). Customer-oriented approaches to identifying product-markets. Journal of Marketing, 43, 8-19.

Delre, S. A., Jager, W., Bjjmolt, T. H. A., \& Janssen, M. A. (2007). Targeting and timing promotional activities: An agent-based model for the takeoff of new products. Journal of Business Research, 60, 826-835.

Dess, G., \& Beard, D. (1984). Dimensions of organizational task environments. Administrative Science Quarterly, 29, 52-73.

Di Benedetto, C. A. (1999). Identifying the key success factors in new product launch. The Journal of Product Innovation Management, 16, 530-544.

Dickson, P. R. (1992). Toward a general theory of competitive rationality. Joumal of Marketing, 56, 69-83.

Dickson, P. R., Farris, P. W., \& Verbeke, W. J. M. I. (2001). Dynamic strategic thinking. Journal of the Academy of Marketing Science, 29, 216-237.

Dickson, P. R., \& Giglierano, J. (1986). Missing the boat and sinking the boat: A new model of entrepreneurial risk. Journal of Marketing, 50, 58-70.

Dickson, P. R., \& Ginter, J. L. (1987). Market segmentation, product differentiation, and marketing strategy. Journal of Marketing, 51, 1-10.

D'Souza, G., \& Rao, R. C. (1995). Can repeating an advertisement more frequently than the competition affect brand preference in a mature market? Journal of Marketing, 59, 32-42.

Dugal, S. S., \& Roy, M. H. (1996). The allocation of R\&D funds between product development and process improvements: A follow-up study. Journal of Strategic Marketing, 4, 117-127.

Dutton, J., \& Dukerich, J. (1991). Keeping an eye in the mirror: Image and identity in organizational adaptation. Academy of Management Joumal, 34, 517-554.

Edward, T. (1972). HIT - Heuristic ideation technique - A systematic procedure for new product search. Journal of Marketing, 36, 58-61.

Eisenhardt, K. M., \& Tabrizi, B. N. (1995). Accelerating adaptive processes: Product innovation in the global computer industry. Administrative Science Quarterly, 40, 84-110.

Emery, F., \& Trist, E. (1965). The causal texture of organizational environments. Human Relations, $18,21-32$.

Fiol, M., \& Lyles, M. (1985). Organizational learning. Academy of Management Review, 10, $803-813$.

France, P. (1996). Chemical engineering. New York, 103, 113-114.

Franke, N., Keinz, P., \& Steger, C. (2009). Testing the value of customization: When do customers really prefer products tailored to their preferences? Journal of Marketing, 73, 103-121.

Fredrickson, J. (1983). Strategic process research: Questions and recommendations. Academy of Management Review, 8, 565-575.

Futrell, C. M., \& Parasuraman, A. (1984). The relationship of satisfaction and performance to salesforce turnover. Journal of Marketing, 48, 33-40.

Galbraith, J. (1977). Organizational design. Reading, MA: Addison-Wesley.

Galbreath, J., \& Galvin, P. (2008). Firm factors, industry structure and performance variation: New empirical evidence to a classic debate. Journal of Business Research, 61, 109-117.

Gatignon, H., \& Xuereb, J.-M. (1997). Strategic orientation of the firm new product performance. Joumal of Marketing Research, 34, 77-90.

Grant, J., \& King, W. R. (1982). The logic of strategic planning. Boston: Little, Brown.

Grewal, R., \& Tansuhaj, P. (2001). Building organizational capabilities for managing economic crisis: The role of market orientation and strategic flexibility. Journal of Marketing, 65, 67-80.

Gwynne, P. (1997). Skunk works, 1990s-style. Research Technology Management, 40, 18-23.

Han, J. K., Kim, N., \& Kim, H. (2001). Entry barriers: A dull-, one-, or two-edged sword for incumbents? Unraveling the paradox from a contingency perspective. Journal of Marketing, $65(1), 1-14$.

Harris, C., \& Kleiner, B. H. (1993). Motivational practices at America's best managed companies. Management Research News, 16(9,10), 1-5.

Hart, S. L. (1992). An integrative framework for strategy-making processes. Academy of Management Review, 17, 327-351. 
Hart, S. L., \& Banbury, C. (1994). How strategy-making processes can make a difference. Strategic Management Journal, 15, 251-269.

Hatten, K. J., \& Schendel, D. E. (1977). Heterogeneity within an industry: Firm conduct in the U.S. brewing industry. The Journal of Industrial Economics, 26, 97-113.

Helms, M. M., \& Nixon, J. (2010). Exploring SWOT analysis - Where are we now? Journal of Strategy and Management, 3, 215-251.

Henderson, B. D. (1979). Henderson on corporate strategy. Cambridge: Abt Books.

Hise, R. T., O'Neal, L., Parasuraman, A., \& McNeal, J. U. (1990). Marketing/R and D interaction in new product development: Implications for new product success rates. Journal of Product Innovation Management, 7, 142-155.

Homburg, C., \& Bucerius, M. (2005). A marketing perspective on mergers and acquisitions: How marketing integration affects postmerger performance. Journal of Marketing, 69, 95-113.

Homburg, C., Steiner, V., \& Totzek, D. (2009). Managing dynamics in a customer portfolio. Journal of Marketing, 73, 70-89.

Hooley, G. H. (1995). The lifecycle concept revisited: Aid or albatross? Journal of Strategic Marketing, 3, 23-39.

Holtzman, Y. (2011). Strategic research and development: It is more than just getting the next product to the market. Journal of Management Development, 30, 126-133.

Houston, M. B., Ratneshwar, S., Ricci, L., \& Malter, A. J. (2010). Dynamic strategic goal-setting: Theory and initial evidence. Review of Marketing Research, 7, 19-62.

Hume, S. (1992). Brand loyalty steady. Advertising Age, 63, 19.

Jaworski, B. J. (1988). Toward a theory of marketing control: Environmental context, control types, and consequences. Joumal of Marketing, 52, 23-39.

Karakaya, F., \& Kerin, R. A. (2007). Impact of product life cycle stages on barriers to entry. Journal of Strategic Marketing, 15, 269-280.

Kaul, A. (2012). Technology and corporate scope: Firm and rival innovation as antecedents of corporate transactions. Strategic Management Joumal, 33, 347-367.

Ketchen, D. J. Jr., \& Hult, T. M. (2011). Marketing and organization theory: Opportunities for synergy. Journal of the Academy of Marketing Science, 39, 481-483.

Kohli, A. K., \& Jaworski, B. J. (1990). Market orientation: The construct, research propositions, and managerial implications. Joumal of Marketing, 54(2), 1-18.

Kotabe, M., Sahay, A., \& Aulakh, P. S. (1996). Emerging role of technology licensing in the development of global product strategy: Conceptual framework and research propositions. Journal of Marketing, 60, 73-88.

Kotler, P. (1980). Marketing management: Analysis, planning, and control (4th ed.). Engelwood Cliffs, NJ: Prentice-Hall.

Kotler, P. (1984). Marketing management: Analysis, planning and control. Englewood Cliffs, NJ: Prentice-Hall.

Kraimer, M. L., Seibert, S. E., Wayne, S. J., Liden, R. C., \& Bravo, J. (2011). Antecedents and outcomes of organizational support for development: the critical role of career opportunities. Joumal of Applied Psychology, 96, 485-500.

Krasnikov, A., \& Jayachandran, S. (2008). The relative impact of marketing, research-anddevelopment, and operations capabilities on firm performance. Journal of Marketing, 72(4), $1-11$.

Lambkin, M., \& Day, G. S. (1989). Evolutionary processes in competitive markets: Beyond the product life cycle. Journal of Marketing, 53, 4-20.

Langerak, F., Hultink, E. J., \& Robben, J. (2004). The role of predevelopment activities in the relationship between market orientation and performance. $R \& D$ Management, 34, 295-309.

Lee, T. Y., \& Bradlow, E. T. (2011). Automated marketing research using online customer reviews. Joumal of Marketing Research, 48, 881-894.

Lloyd, G. C. (1996). Thinking beyond the box. Health Manpower Management, 22, 37-39.

Løwendahl, B., \& Revang, O. (1998). Challenges to existing strategy theory in a postindustrial society. Strategic Management Journal, 19, 755-773.

Makadok, R., \& Barney, J. B. (2001). Strategic factor market intelligence: An application of information economics to strategy formulation and competitor intelligence. Management Science, 47, 1621-1638.

Matsuno, K., Mentzer, J. T., \& Ozsomer, A. (2002). The effects of entrepreneurial proclivity and market orientation on business performance. Journal of Marketing, 66, 18-32. 
Maxwell, R., \& Knox, S. (2009). Motivating employees to "live the brand": a comparative case study of employer brand attractiveness within the firm. Journal of Marketing Management, 25, 893-907.

McArthur, A. W., \& Nystrom, P. C. (1991). Environmental dynamism, complexity, and munificence as moderators of strategy-performance relationships. Journal of Business Research, 23, 349-361.

Menon, A., Bharadwaj, S. G., Adidam, P. T., \& Edison, S. W. (1999). Antecedents and consequences of marketing strategy making: A model and a test. Journal of Marketing, 63, 18-41.

Michlitsch, J. F. (2000). High-performing, loyal employees: The real way to implement strategy. Strategy and Leadership, 28, 28-33.

Miles, R., \& Snow, C. C. (1978). Organizational strategy, structure, and process. New York, NY: McGraw-Hill.

Miller, D. (1989). Matching strategies and strategy-making: Process, content, and performance. Human Relations, 42, 241-260.

Mintzberg, H. (1973). Strategy making in three modes. California Management Review, I6, 44-53.

Mintzberg, H. (1987). Crafting strategy. Harvard Business Review, 65, 66-75.

Mintzberg, H., \& McHugh, A. (1985). Strategy formation in an adhocracy. Administrative Science Quarterly, 30, 160-197.

Mintzberg, H., \& Waters, J. A. (1985). Of strategies, deliberate and emergent. Strategic Management Journal, 6, 257-272.

Montoya-Weiss, M., \& Calantone, R. (1994). Determinants of new product performance: A review and meta-analysis. Joumal of Product Innovation Management, 11, 397-417.

Moorman, C., \& Miner, A. S. (1998). The convergence of planning and execution: Improvisation in new product development. Journal of Marketing, 62(July), 1-20.

Murray, E. A. (1978). Strategic change as a negotiated outcome. Management Science, 24, 960-972.

Nadeau, J., \& Casselman, R. M. (2008). Competitive advantage with new product development: Implications for life cycle theory. Journal of Strategic Marketing, 16, 401-411.

Nonaka, I. (1988). Toward middle-up-down management: Accelerating information creation. Sloan Management Review, 29, 9-18.

Nutt, P. (1981). Some guides for the selection of a decision-making strategy. Technological Forecasting and Social Change, 19, 133-145.

O’ Regan, M., Kalidas, A., Maksimova, O., \& Reshetin, O. (2011). Optimizing market segmentation for a global mobile phone provider for both targeting and insight. Joumal of Advertising Research, 51, 571-577.

Park, H. D., \& Steensma, H. K. (2012). When does corporate venture capital add value for new ventures? Strategic Management Journal, 33(1), 1-22.

Parnell, J. A., \& Lester, D. L. (2003). Towards a philosophy of strategy: Reassessing five critical dilemmas in strategy formulation and change. Strategic Change, 12, 291-303.

Pascale, R. (1985). The paradox of 'corporate culture': Reconciling ourselves to socialization. California Management Review, 27, 26-41.

Payne, A., \& Frow, P. (2006). Customer relationship management: From strategy to implementation. Journal of Marketing Management, 22, 135-168.

Pelham, A. M. (1999). Influence of environment, strategy, and market orientation on performance in small manufacturing firms. Joumal of Business Research, 45, 33-46.

Pfeifer, P. E., \& Carraway, R. L. (2000). Modeling customer relationships as Markov chains. Journal of Interactive Marketing, 14, 43-55.

Porter, M. E. (1980). Competitive strategy. New York, NY: Free Press.

Porter, M. E. (1985). Competitive advantage: Creating and sustaining superior performance. New York, NY: Free Press.

Ratneshwar, S., Shocker, A. D., Cotte, J., \& Srivastava, R. K. (1999). Product, person, and purpose: Putting the consumer back into theories of dynamic market behavior. Joumal of Strategic Marketing, 7, 191-208.

Rese, A., \& Baier, D. (2011). Success factors for innovation management in networks of small and medium enterprises. $R$ and $D$ Management, 4I, 138-155.

Reinartz, W., \& Kumar, V. (2002). The mismanagement of customer loyalty. Harvard Business Review, 80, 86-94.

Rink, D. R., Roden, D. M., \& Fox, H. W. (1999). Financial management and planning with the product life cycle concept. Business Horizons, 42, 65-72. 
Rink, D. R., \& Swan, J. E. (1979). Product life cycle research: A literature review. Jounal of Business Research, 7, 219-242.

Rudd, J. M., Greenley, G. E., Beatson, A. T., \& Lings, I. N. (2008). Strategic planning and performance: Extending the debate. Joumal of Business Research, 61, 99-108.

Salmela-Aro, K., Mutanen, P., \& Vuori, J. (2012). Promoting career preparedness and intrinsic work-goal motivation: RCT intervention. Journal of Vocational Behavior, 80, 67-75.

Schmitt, P., Skiera, B., \& Bulte, C. (2011). Referral programs and customer value. Journal of Marketing, 75, 46-59.

Schoonhoven, C. B., Eisenhardt, K. M., \& Lyman, K. (1990). Speeding products to market: Waiting time to first product introduction in new firms. Administrative Science Quarterly, 35, 177-207.

Shipp, S. H., \& Lamb, C. W. Jr. (1996). The effect of selected environmental variables on the marketing mix/SBU performance relationship. Journal of Strategic Marketing, 4, 143-162.

Silverblatt, R., \& Korgaonkar, P. (1987). Strategic market planning in a turbulent business environment. Journal of Business Research, 15, 339-358.

Sirmon, D. G., Hitt, M. A., \& Ireland, D. R. (2007). Managing firm resources in dynamic environments to create value: Looking inside the black box. Academy of Management Review, $31,273-292$.

Slater, S. F., \& Olson, E. M. (2001). Marketing's contribution to the implementation of business strategy: An empirical analysis. Strategic Management Journal, 22, 1055-1067.

Slotegraaf, R. J., \& Dickson, P. R. (2004). The paradox of a marketing planning capability. Journal of the Academy of Marketing Science, 32, 371-385.

Song, X. M., \& Parry, M. (1997). The determinants of Japanese new product success. Journal of Marketing Research, 34, 64-76.

Sood, A., \& Tellis, G. (2005). Technological evolution and radical innovation, Journal of Marketing, $69,152-168$.

Srinivasan, R., Lilien, G. L., \& Sridhar, S. (2011). Should firms spend more on research and development and advertising during recessions? Journal of Marketing, 75, 49-65.

Tadepalli, R., \& Avila, R. A. (1999). Market orientation and the marketing strategy process. Joumal of Marketing Theory and Practice, 7, 69-82.

Talke, K., \& Hultink, E. J. (2010). Managing diffusion barriers when launching new products. Journal of Product Innovation Management, 27, 537-553.

Tegarden, L. F., Sarason, Y., \& Banbury, C. (2003). Linking strategy processes to performance outcomes in dynamic environments: The need to target multiple bull's eyes. Journal of Managerial Issues, 15, 133-153.

Thietart, R. A., \& Vivas, R. (1984). An empirical investigation of success strategies for businesses along the product life cycle. Management Science, 30, 1405-1423.

Treacy, M., \& Wiersema, F. (1993). Customer intimacy and other value disciplines. Harvard Business Review, 71, 84-93.

Urban, G. L., \& Hauser, J. R. (1993). Design and marketing of new products. Englewood Cliffs, NJ: Prentice Hall.

Valentini, G. (2012). Measuring the effect of M \& A on patenting quantity and quality. Strategic Management Journal, 33, 336-346.

Varadarajan, R. (2011). Marketing strategy: Discerning the relative influence of product and firm characteristics. Academy of Marketing Science Review, 1, 32-43.

Venkatesan, R., Kumar, V., \& Bohling, T. (2007). Optimal CRM using Bayesian decision theory: An application for customer selection. Journal of Marketing Research, 44, 579-594.

Vesper, K. (1980). New venture strategies. Englewood Cliffs, NJ: Prentice Hall.

von Hippel, E. (1978). Successful industrial products from customer ideas. Journal of Marketing, 42, $39-49$.

Walker, O. C., \& Ruekert, R. W. (1987). Marketing's role in the implementation of business strategies: A critical review and conceptual framework. Joumal of Marketing, 51, 15-33.

Weick, K. E. (1987). Organizational culture as a source of high reliability. California Management Review, 29, 112-127.

Weitz, B. A., \& Wensley, R. (1984). Strategic marketing: Planning, implementation, and control. Boston: Kent Pub. Co.

Wood, R. D. Jr., \& Laforge, L. R. (1979). The impact of comprehensive planning on financial performance. Academy of Management Journal, 22, 516-526. 
Yeniyurt, S., Townsend, J. D., \& Talay, M. B. (2007). Factors influencing brand launch in a global marketplace. Journal of Product and Innovation Management, 24, 471-485.

Zeithaml, B., \& Parasuraman, A. (1988). Communication and control processes in the delivery of service quality. Joumal of Marketing, 52, 35-48.

Zirger, B. J., \& Maidique, M. (1990). A model of new product development: An empirical test. Management Science, 36, 867-883. 